\title{
Women Predicament in 'A Journey on Bare Feet' by Dalip Kaur Tiwana
}

Dr. Rajni Sharma,

Department of English,

Ch. Balluram Godara Govt. Girls College,

Sri Ganganagar, India

rajanisharma414@gmail.com

Mrs. Poonam Gaur

Lecturer in English

Ch. Mota Ram Meel Memorial (PG) College

74 LNP, Padampur, India

poonam.gautam1975@gmail.com

\begin{abstract}
The autobiographical impulse and act is central to woman's writing in India. The range of Indian women's writing generates an unending discourse on personalities, woman's emotions and ways of life. In a way, it presents the socio-cultural state in India from a woman's stance. It affords a peep into Indian feminism too. Besides giving a historical perspective, it throws ample light on woman's psychic landscape. It takes us to the deepest emotions of a woman's inner being. The varied aspects of woman's personality find expression in the female autobiographical literature. We find that a deeper study of women's autobiographies unravel the hidden recesses of feminine psyche of Indian society. What so ever the position of women
\end{abstract}


may be, behind every social stigma, there is woman, either in the role of mother-in-law, sister-in-law or wife. The women writers with sharp linguistic, cultural and geographical environment represented the problems and painful stories of Indian women from 19th century until date. However, they have not shared the contemporary time of the history, the problems of patriarchal society, treatment women, broken marriages and the identity crises for the women remained similar. Women writers have also been presenting woman as the centre of concern in their novels. Women oppression, exploitation, sob for liberation are the common themes in their fiction.

Dalip Kaur Tiwana is one of the most distinguished Punjabi novelists, who writes about rural and innocent women's physical, psychological and emotional sufferings in a patriarchal society. As a woman she feels women's sufferings, problems, barricades in the path of progress as well as the unrecognized capabilities in her. Dalip Kaur Tiwana has observed Indian male dominated society very closely and has much understanding of social and ugly marginalization of women. She can be considered a social reformer as she is concerned with human conditions and devises for the betterment of women's condition in Indian Punjabi families. This paper focuses on the theme of feminist landscape . It presents the miserable plight of women characters she has come across since her childhood. Women, who felt marginalized, alienated, isolated and detached in their lives, but were helpless as no law was there in her time to punish the outlaws. Dalip Kaur Tiwana beautifully portrays the landscape of her mind. The paper shows how Dalip Kaur Tiwana presents the unfortunate image of her mother, grandmother aunts and some other obscure women who were unable to mete out justice during their life time.

Keywords - Marginalized, Feminine Psyche, Alienation, Oppression, Detachment And Existential Crisis. 
I. Introduction

A Journey on Bare Feet is a pathetic life story of Dalip Kaur Tiwana, a celebrated Punjabi writer. This book is considered an anthropological statement or study on feminine condition in the lower peasantry of Punjab. Dalip Kaur Tiwana has presented the miserable plight of oppressed women in a rural patriarchal set up of Punjab. Tiwana's feminist framework unfolds the subjective position of the voiceless and marginalized women, who are toiling creatures leading their lives as beasts of burden and as victims of dominant caste onslaught. It is but natural that they are mute. The reader gets practical and genuine glimpses of the lives of women through the creative writing A Journey on Bare Feet of Tiwana, which is a historical memoir. She says in about the book:

"It is a history, history of those who have borne it (on their bodies) long before, it is written on the pages of history. This autobiography is dedicated in remembrance to those who have endured history on themselves".

\section{Women Predicament in 'A Journey On Bare Feet' by Dalip Kaur Tiwana}

Even if the narrative depicts Tiwana's life history, yet it is a history of Punjabi culture, rituals and beliefs as well. Although Tiwana's account is essentially personal, her struggle is the struggle of every Indian woman. Several concerns of women such as dowry, women's education, the general preference for sons and status of women, drinking habit of males, early marriage of girls, quarrel for property, polygamy in pre-independence time, form an integral part of A Journey on Bare Feet. A Journey on Bare Feet consists of twenty seven chapters without specifying any date and year. Based on its content, this autobiography precisely recounts Tiwana's life from 1935-1980. The time span of forty five years of Tiwana's life is beautifully woven in this work. Born on 4th May in 1935, Dalip Kaur Tiwana in A Journey on Bare Feet recounts her birth in a small village of Rabbon in Ludhiana district 
of Punjab, where she is brought up in a wealthy traditional family of prosperous zamindars. It was the time of pre-independence, there were several princely states in India. Punjab was one such, the then princely state of India which Tiwana describes in this autobiographical account .Tiwana in the backdrop of colonial times highlights the working of zamindari system in the Punjab province.

In her autobiography A Journey on Bare Feet, Tiwana first introduces us to her innocent, uneducated but humble grandmother. She is the central character of the book. Tiwana's grandmother was a simple woman from a Jatt family, married to a rich man, Hazura Singh. Living in a family of zamindars of great repute, her grandmother had never been accustomed to the lifestyle of opulence and grandeur of this royal family. This woman did not have enough money to buy a packet of matches. She was thought to be a menial by her younger daughter. The title of the book is after her, as her younger son got angry with her for going about the house in bare feet, and for wearing old and torn cloths. Afraid to look at her own daughter and son, she held the hand of her grand daughter. The dominance of her grandfather in the house is so much that she can't ask him to accompany her to Hardwar for a dip in the holy river Ganga. She represents Indian woman who is always in the grip of fear without any reason. her grandmother taught Tiwana to live in fear of the Almighty and "his secret dispensation". Her grandmother had lived her life as a stereotyped image of the silent, suffering woman in a village patriarchy. Her marginalized location in an oppressive, casteridden feudalistic society was not unknown to her. Tiwana described the extent of her grandmother's acceptance of her inferior position in a society she lived in by narrating an instance. She described when Tiwana's grandfather gave a sum of hundred rupees to his wife while going to Nabha, the whole of the night her grandmother could not asleep for fear of losing the money. All the time she kept worrying,

"What if I lose it? My parents are in no position to make good the loss". 
Tiwana, on seeing the disturbed state of her grandmother suggested her to spend the money on daily items. Wondering at Tiwana's suggestion her grandmother said to Tiwana,

"What a large heart you have! That's because you belong to an aristocratic family".

Her grandmother knew that she could not even think of spending such a big amount at a go. Tiwana in the narrative traces the dichotomy between classes and its fallout in shaping the psyche of the subalterns into pushing them to internalize their secondary posture in the society. Tiwana has great regard for her grandmother whose unconditional love and preaching has made Tiwana what she is today. Her sense of gratitude for her grandmother lies at the core of her heart, which she acknowledges in these words:

"When I was very small, my grandmother had breast-fed me. Surprisingly, her breasts had filled with milk. I was too young to know why my grandmother had nursed me in place of my mother."

Another very important character in this narrative is Tiwana's mother, Chand Kaur. Chand Kaur was a daughter of a poor peasant Hira Singh. Chand Kaur's mother, Har Kaur was a pious woman who died at a young age leaving behind her seven years old daughter, Chand Kaur and two sons. After her death, Hira Singh and Sadhu Baba Bhagwandas looked after the children with great care. Baba Bhagwandas left no stone unturned in bringing them up as his own children. He made Chand Kaur memorize "five scriptures, the sayings of the saints and the Granth Saheb with all its commentaries." His religious discourses too have enlightened her mind which, henceforth, had made her a devotee like her mother Har Kaur. His kinship for the family was immeasurable. It was only he who accompanied Hira Singh to Tiwana's family with an offer of Chand Kaur's marriage to their son, Kaka Singh. In A Journey on Bare Feet Tiwana also narrates her mother's journey in Rabbonwalli family of zamindars. She describes her as 
"A dark and youthfully attractive woman who used to go about the house, unobtrusively, attending to her chores, and of whom I had never taken much notice."

She also has made a journey of her life barefoot, i. e. she is resource less. She was a neglected woman in the family because she had not given birth to any son, an heir to carry on the lineage of zamindars. She had consecutively given birth to three daughters in a marriage of five years. Besides being cooped up and suffered at the hands of her family members, she had also witnessed the separation from her own daughters, living under one roof. She is helpless when her sister-in -law is taking her daughter away. she had no right either to love or show fondness for her children. . Her colored skin, poor background and being a mother of daughters only serve the chief reasons of her plight in 'Rabbonwalli Family'. Hailing from a poor class, Chand Kaur had also suffered at the hands of zamindari society, where she was forced to bear children till the inclination for a son was realized.

In her essay 'Woman as Other' in Second Sex Simonde Beauvoir aptly points out,

"Woman is womb...We are exhorted to be women, remain women, become women...she is called 'the sex', by which is meant that she appears essentially to the male as a sexual being. For him she is sex-absolute sex, no less. She is defined and differentiated with reference to man and not he with reference to her; she is the incidental, the inessential as opposed to the essential. He is the Subject, he is the Absolute - she is the Other."

In the book, Chand Kaur was treated no less than a 'sex' and 'other'. Preference for a son seems the only reason to perform a marriage in a patriarchal/racial society. Should a woman fail to oblige or live up to the desired standard of the patriarchal society, she is doomed to give grounds for her existence -her sexuality, her womanhood and most of all her identity as constructed by the society? Any failure in regard to society's norms is highly unacceptable. When a third daughter was born to Chand Kaur, almost everyone in the house 
rebuked her. Tiwana's grandmother reprimanded her daughter-in-law -"What good are you if you cannot give us a son' or 'Oh God it's our bad luck that you have fallen to our lot. That bride of peepal tree house took no time in giving birth to two sons in quick succession. A lucky family indeed! And you" .Tiwana's father also threatened to cut his wife (Chand Kaur) into pieces for giving him this sad news of the birth of a third daughter. Chand Kaur is a typical Punjabi woman suffering all her life without any grudge or ambitions. All she needs and prays is the welfare of her offspring. She is hysterical at the time of her husband's death, although he had tormented her a lot.

On seeing the situation worsen Tiwana's grandfather consulted a Purohitji and asked him to find out some way by suggesting some ritual so that his daughter-in-law could bear a son. He was worried over the spate of girls born into the family. Grandfather also wanted to know if the same wife will bear a son or will his son have to marry a second time. In those days second marriage was not a new phenomenon, it was a common practice. This is borne out by the elder aunt's (Gulab Kaur's co-wife) remark when she said,

"It won't make a difference if there are three dead. There will still be a fourth one. Show me a Sardar who has less than four wives".

Here the narrative strongly hints at objectification of women where they are considered as belongings, like things. Chand Kaur's exploitation on the basis of caste, class, race and gender also proved the fact that she was an object to be used and discarded. Tiwana relives those times when polygamy was out of control in India. She brings forth men's oppression while narrating her aunt, Gulab Kaur's story who had been married for quite some time but did not have any child. Gulab Kaur is the second wife of Tiwana's uncle General Sardar Tara Singh Sidhu, the Superintendent of Police at Patiala. He had married again in the hope of getting an heir, but the second marriage also proved fruitless. Gulab Kaur pleaded 
before her parents to send Dalip Kaur with them so that her husband's mind of marrying a third time could be changed.

On Gulab Kaur's request Tiwana was sent away to live with her aunt. Tiwana were three sisters, her elder aunt said to Tiwana's grandfather, "Now that you have two daughters, we shall keep Deep". At this point, Chand Kaur reconciled to her fate when no one asked her consent in sending away her daughter to someone else. Tiwana described her mother's love in abundance in an overwhelming tale of their separation, "She hugged me, stroked my head, my face, my arms and kissed me on my cheeks. Then suddenly burst into tears...Don't forget me. Tell your grandfather that you don't want to go" .Going away of Tiwana was not an insignificant matter for the family. Tiwana's grandfather too with a heavy heart had taken this decision, first to save his daughter's (Gulab Kaur) marriage and second for Tiwana's better prospects. He said with moist eyes, "Sons take her away, if you must. But look after her well. She is more precious to us than seven sons. Put her in a school. I'll pay for her education for a year, to start with" . Tiwana shows how these human relations get entangled in this universe and behave in regard to one-another's interest.

Tiwana's grandmother had always prayed under her breath for a grandson to be born whose light she should be able to see in her lifetime. Tiwana's father was a drunkard and this was also a cause of concern for the family. They wanted a son so that the property could be given to him. Once again the discrimination between a son and a daughter in legal affairs is highlighted. In Zamindar families the settling or handing over the property to the son or grandson was a significant matter and women had to continue the process of breeding till the heir of the property was born. This custom later on led to female feticide when ultra sound machines came into existence. Tiwana and her two sisters could not have a rightful share in their father's property. The birth of a son was therefore necessary. Emphasizing on the 
importance of a male child in a socio-cultural fabric, Jaiwanti Dimri in 'Images and Representation of the Rural Women' appropriately writes,

"In a superior social space in a patriarchal setup where reproduction for women is an imperative (and), the reproduction of male progeny is a necessity".

It was after many years of prayers that a son after five daughters was born in their family. Tiwana at last had a brother. He was named Verendra Singh. On this auspicious occasion, Bishan Purohit performed many rituals. Grandmother lavishly distributed wheat and jaggery among the poor. Many other gifts were also doled out like phulkaris, dopatta, thick cotton bed sheets, hard cash and buffaloes among the people of the village. Bishan Purohit also predicted that the child would be long-lived, wealthy and influential. Tiwana's grandmother was anxious to know whether he would lead a normal life or follow in his father's footsteps, to which Purohitji replied to her contentment and said,

"He has taken after her mother's family... He will prove a lucky boy."

At this juncture, Tiwana's mother, Chand Kaur, who was doomed otherwise, was given some respect once the son was born to her. The result of Chand Kaur's self-punishment has stood her in good stead. In a feudalistic society, giving birth to a son means a lot for the family but it does not mean woman's liberation in any way. At the most, it implies that Chand Kaur is now free of indictable blame of bearing a son. Tiwana's preoccupation with women's sensibility, gender practices, and identities have proceeded to articulate and demand contemplation on part of the society's code of conduct. Tiwana records in her autobiography another problem usually faced by the girls in Indian society. Tiwana recalls the time when her marriage was settled. In her younger days girls were presented before the groom as a commodity. He would either accept her or reject her as per his choice. Girls had to tolerate the insult helplessly. When a month was left for the wedding, the parents of the boy broke off the engagement. In Tiwana's house the preparation for the marriage had started on a 
hectic note. It was a stigma for her family as the rejected girls are a problem for the family to remarry. Tiwana's elder Aunt, Gulab Kaur said,

"People would wonder why they had rejected a daughter of their family. It will bring us bad name.".

When the proposal was called off, Tiwana's self confidence was shattered, comments and taunts only added her disappointment. Sometimes, she would stand before the mirror and had doubts over her looks and appearance. She wondered, wasn't she a good girl. Why did they accuse her of no-character girl? The rejection of Tiwana for marriage after it had been settled was a very serious matter because it could affect the prospects of Tiwana's sisters as well. When Samrala aunt came to know about the news she came rushing to Patiala again with her proposal and started plotting the whole affair with an eye to fix up the proposal of Tiwana's marriage with her sister-in-law's son. She spoke in such a sarcastic tone,

"What belongs to the garbage dump must ultimately find a place there. Girls can't live in their parent's homes all their lives. They must go where they belong. Here's a good opportunity coming your way. Of course, you can try in other place. Nobody can stop you from doing that. But they would all insinuate that she is a once rejected girl, you may find yourself at a dead end."

Her talks even indicated a reference to dowry while covering up all the points, “Whatever you want to give, you can put it in girls' name”.

Girls in India are not asked their choice in the matter of their marriage. Her aunt took no time in finalizing the marriage date without seeking her permission. Tiwana recalls, "They asked me nothing, told me nothing. I felt lost and forlorn in the melee, marked by the din and hubbub of a country fair. After school, I went straight to my room and read. Lost in the world of fiction I would soon forget the real world around me." Tiwana took four pheras around Guru Granth Sahib and then departed to her in-laws house, within few days. Tiwana 
was just in eighth standard when she got married. Being a young girl of twelve years; yet to come of age, she was sent back the following day to be retrieved back after two years from her parental house. After getting married, Tiwana resumed her studies as before, after a day's absence.

In the narrative Tiwana talked about her identity crisis when Miss Sen, her school teacher asked her, 'Miss Tiwana would you like to continue studies?' Tiwana had wanted to remind her teacher that she was no longer Miss Tiwana. Tiwana described her dilemma in these lines, "Then what was I. It struck me that I was nobody. Yes, I was nobody. When someone addressed me as Miss Tiwana I felt like that I was leading a false life".

In India girls' career is not considered seriously. Tiwana discusses the matter in the book earnestly. She feels insulted and cheated when she rejoins the school after marriage. All girls are not so lucky to get this chance. Because of early marriage sometimes boys' career is also ruined Indian government had to declare early marriage a crime, which has checked this social evil to a great extent. Raghubir Bhai ,Tiwana's cousin also became a victim to the affects of early marriage. He said, "At that time I was still in school. My parents never asked me about my opinion... But why Should I be made to suffer for it?"

Tiwana has woven various other threads while narrating her own story. Tiwana unfolds the strange story of an orphan girl child named Dhanni. As the story goes, when Tiwana's uncle was the City Kotwal, a woman lodged a complaint that her husband had picked up a girl from somewhere and had brought her home. After interrogation the police revealed the facts that Dhanni's step mother had sold her off to some unknown person who in turn had again passed her on to a stranger. Now, her step mother was not willing to take her back. Tiwana's uncle General Sardar Tara Singh Sidhu pitied the girl and adopted her as his own daughter. When she grew up Tiwana's uncle married her off to the brother-in-law of the 
Superintendent of Police of Dhaliwal. Unfortunately, her marriage came to a halt when her husband started ill treating her for extravagant demand of money in order to pay off his family debts. Initially, she pacified him by taking money from her foster father (Tiwana's uncle), later he began harassing her all the more. Unable to bear his cruelty for a long time, she refused to live with him. On her foster mother's (General Tara Singh Sidhu's first wife) askance, "But where will you live if you leave your husband? Dhanni in an anguish replied, "I will live neither here nor there. I will not live anywhere". Her ominous words came true when she died of enteric fever bringing her story to a sad end.

Another instance, Tiwana unveils is about Baldev Kaur's sister-in-law. Everybody was told that she died by falling from the roof top. But Tiwana's grandfather's remarks in this context arise doubts in the mind. He said to Baldev Kaur, his daughter who came with a proposal of Tiwana's marriage with her sister-in-law's son, "Don't try to teach me. I just don't want to marry the girl into their family. How do you know the boy's mother fell from the roof by accident and wasn't pushed down?...People know only what they are told".

In those days killing an unwanted bride was a very easy game. Tiwana here depicts various social injunctions working at the grassroots in a socio-cultural familial setup where the termination of a woman is put forward as an accident so to suppress the voice forever. Dalip Kaur Tiwana presents the plight of both, rural and urban women where one unfailingly attend to all the household chores and suffers all tortures, while the other though educated struggles unavailingly against her fate before she resignedly accepts her lot in life and decides to live barely and humbly as strange silent others. Tiwana probes the mind, the sensibility, the agitated heart of the lonely or trapped woman. 


\section{Conclusion}

We find that a deeper study of women's autobiographies unravel the hidden recesses of feminine psyche of Indian society. The autobiography by Tiwana reveals that woman has secondary position in the family and society. Whether she hails from higher class or lower class her destiny is same. Autobiographies from the time of Suniti Devi to Shobha De have the same script; pain, disappointment, helplessness and frustration. The women writers are agents to bring change in the society through their autobiographies they have paved the way for progeny and acclaim that with willpower everything can be changed. As regarding, the narratives by the women writers Estelle, $\mathrm{C}$ has her own views,

"Women's self- image is projected by the very means used to distance or detach themselves. In their life stories, a variety of forms of understatement in place of growing narratives, women tend to write in a straight forward and objective manner about both their girlhood and adult experiences.', 


\section{References}

Tiwana, Dalip Kaur, A Journey on Bare Feet, Sangam Books Ltd., 1990

The Criterion: An International Journal in English Vol. 8, Issue-V, October 2017

Tiwana, Dalip Kaur, Twilight Mark of The Nose Ring, Nation Book Trust, 2001

Tiwana, Dalip Kaur, Tell the Tale, Urvashi, Orient Blackswan Private Limited, 2016

Tiwana, Dalip Kaur, Yahi Hamara Jeena, Balaji World of Books, 2008 